\title{
"Como Ocorre a Construção e Disseminação do Conhecimento Curricular Freireano?" Algumas Sinalizações
}

\section{Some Thoughts on How the Construction and Dissemination of Freire's Curriculum Knowledge Take Place}

\author{
(D) Thiago Flores Magoga, ${ }^{\text {(D) }}$ Cristiane Muenchen
}

Palavras-chave Resumo A obra Freireana tem sido reinventada e adaptada à Tema Gerador;

Currículo; Historicidade; Paulo Freire;

Revisão diferentes realidades e muitos conhecimentos teóricos e práticos foram construídos, principalmente na área de Ensino de Ciências. Uma das dimensões desses conhecimentos abrange o campo curricular, em que a perspectiva dos Temas Geradores se materializa. O presente trabalho, Bibliográfica. portanto, tem por objetivo sinalizar alguns elementos e contextos importantes, os quais auxiliam na construção e disseminação do conhecimento curricular Freireano. Para tanto, utilizando do critério de busca "Tema Gerador" foi realizada uma revisão bibliográfica nos principais eventos da área, de modo que desta resultaram cento e dez produções. Análises cienciométricas possibilitam observar que as obras Pedagogia do Oprimido e Ensino de Ciências: fundamentos e métodos são elementos importantes para o contato e disseminação da perspectiva curricular Freireana. Ainda, por meio da Análise Textual Discursiva, foi possível constatar que a dialogicidade, a problematização, a contextualização e a interdisciplinaridade são elementos que mostram como o Tema Gerador tem sido estruturado. Ademais, foi possível observar nomes de instituições nas quais se produzem trabalhos com a temática Freireana, sendo as principais: a Universidade Estadual de Santa Cruz, Federal de Santa Maria e Federal de Santa Catarina. Por fim, argumenta-se sobre trabalhos que continuem a analisar como pensam e o que fazem os educadores Freireanos para que possa salvaguardar tais conhecimentos. 
Keywords Abstract Freire's work has been reinvented and adapted to different Generative Themes; realities, and much theoretical and practical knowledge has been

Curriculum; built, mainly in the field of Science Teaching. One of the dimensions Historicity; of this knowledge comprehends the curriculum field, in which the

Paulo Freire; generative themes materialize. Thus, this paper aims to indicate some Literature Review. important elements and contexts that support the construction and dissemination of Freire's curriculum theory. For that, we carried out a bibliographic review of important education events in Brazil using "generative theme" as the search criteria, and the query returned one hundred and ten studies. Scientometric analysis made it possible to observe that Freire's Pedagogy of the Oppressed and Delizoicov's Ensino de Ciências: fundamentos e métodos are important elements for understanding and disseminating Freire's curriculum knowledge. Besides, we used discursive textual analysis to verify that dialogicity, problematization, contextualization and interdisciplinarity are elements that show how generative themes have been structured. Furthermore, we noticed that the State University of Santa Cruz, Federal University of Santa Maria and Federal University of Santa Catarina are the institutions where most studies on Freire's theory are conducted. Finally, we highlight the importance of keeping on analyzing how Freirean educators think and what they do in order to safeguard such knowledge.

\section{Introdução}

Nos dias atuais, resgatar a historicidade da obra Freireana, mais do que uma celebração ao centenário de Freire, é um compromisso social de todo(a) o(a) educador(a) autêntico(a). Denunciar as inverdades associadas ao patrono da educação brasileira e anunciar sua obra, seu legado, é - e sempre será - um ato político transformador, de modo que a pesquisa, a escrita científica, o compartilhamento de ideias e práticas são caminhos essenciais à construção e disseminação destes conhecimentos.

Exemplos de tais movimentos não faltam e, neste sentido, faz-se menção ao diálogo "Paulo Freire e a Educação em Ciências (homenagem à Marta Pernambuco e aos mais de 50 anos do Livro Pedagogia do Oprimido)", promovido no XII Encontro Nacional de Pesquisa em Educação em Ciências. O painel de abertura constituiu-se não apenas como um memorial à professora Marta Pernambuco mas, sendo isto, trouxe à tona o protagonismo de Freireanas e Freireanos que cotidianamente trabalham, pesquisam, lutam e inspiram tantos outros sujeitos.

A proposta central deste artigo versa exatamente sobre a historicidade curricular de Freire, a qual potencializou o nascimento e crescimento de uma legião de "filho(a)s, neto(a)s, bisneto(a)s e trineto(a)s", em prol da construção de uma sociedade mais justa, igualitária e desenvolvida (Voltas et al., 2021). 
Talvez nunca se tenha questionado e duvidado tanto dos contributos de Freire como na época atual. Dessa forma, faz-se necessário tecer comentários sobre a necessidade de defender e reinventar Freire, de modo crítico e veemente (Ingrassia, 2018). A subjetividade Freireana pode ser vista - por aqueles que não o entendem como uma crítica, em relação à constante objetividade pela qual aqueles são cobrados cotidianamente em seus locais de serviço. $\mathrm{O}$ fato da poeticidade dos escritos Freireanos serem como são, podem acarretar uma estigmatização, tanto dos sujeitos Freireanos quantos dos críticos aos Freireanos.

Freire e sua obra são tão amplos que suas qualidades podem se tornar suas próprias críticas. Isto é, suas teses são tão vastas que não fornecem uma fronteira tão necessária para profissionais do ensino. Torna-se muito fácil perder o controle de sua obra e acabar cometendo excessos, como querer teorizá-lo demasiadamente ou praticálo incansavelmente. Metaforicamente, assemelha-se aquele sujeito que, ao adentrar em um gigantesco e límpido lago, se encanta tanto que sai da sua margem de segurança e se perde.

Esta imensidão e complexidade de sua obra - essência fundamental e necessária - pode não ser tão aceita por quem precisa e/ou pretende trabalhar no viés Freireano. Esta talvez seja a principal premissa da retórica pergunta: como implementar "Paulo Freire" em um sistema de ensino?

No modelo de sociedade e escola hegemônicos, atuais, trata-se de um desafio, com toda a certeza. Por isso mesmo, é necessário iluminar e trazer à tona o trabalho Freireano nas escolas e universidades brasileiras. Torna-se fundamental mostrar que há muito a se fazer, mas também enaltecer muitos trabalhos já realizados, de excelência, e que podem contribuir com a educação de crianças, jovens e adultos brasileiros (Watanabe, 2019; Delizoicov et al., 2020). Há conhecimentos e práticas curriculares Freireanos!

Entende-se que a perspectiva curricular Freireana compreende elementos, sujeitos, contextos e está associada à proposta dos Temas Geradores. Nesse sentido, situa-se o presente trabalho, o qual é um recorte de uma pesquisa mais ampla a qual visa discutir a produção e disseminação de conhecimentos e práticas Freireanas no Ensino de Ciências ${ }^{1}$ No presente recorte serão apresentados alguns resultados oriundos de uma revisão bibliográfica desenvolvida em eventos da área e o foco central, portanto, está em sinalizar alguns elementos e contextos associados à perspectiva curricular dos Temas Geradores, no campo do Ensino de Ciências, resgatando a historicidade e potencializando caminhos ao estudo deste objeto do conhecimento.

Argumenta-se que a análise dos contextos (locais de produção de conhecimento) e de elementos (formas de estruturar/disseminar) Freireanos possibilita a compreensão de como construir currículos nessa perspectiva, enaltece ideias e práticas e busca sinalizar respostas às questões associadas à polissemia dos Temas Geradores, pois, como defendido por Fonseca et al. (2015) e Magoga (2021), é necessário observar como se dá a proposição curricular Freireana e estabelecer parâmetros de análise.

1 No trabalho de Magoga (2021), no prelo, faz-se uma análise epistemológica - com base em Fleck — da constituição de coletivos de pensamento e incita-se a pensar sobre um Estilo de Pensamento Curricular Freireano. 


\section{Aspectos teóricos-metodológicos}

Discutir currículos não passa apenas pela análise de como aplicá-los (como uma discussão metodológica), mas, especialmente, sobre como construí-los. Pensar e estruturar currículos deve ser um processo democrático, com a participação de diferentes sujeitos, a partir de suas próprias necessidades e não deve atender, somente, a interesses mercadológicos e editoriais (Amestoy \& Tolentino-Neto, 2020).

Atendendo a tal proposta, de discussões curriculares, o principal objeto de análise deste trabalho envolve o Tema Gerador Freireano. A construção de um currículo baseado em Temas Geradores, para Silva (2011) possui características que, quando analisadas sobre o viés de uma educação formal, o caracteriza como um currículo crítico:

Parece evidente que Paulo Freire não desenvolveu uma teorização específica sobre currículo. Em sua obra, entretanto, como ocorre com outras teorias pedagógicas, ele discute questões que estão relacionadas com aquelas que comumente estão associadas com teorias mais propriamente curriculares. Pode-se dizer que seu esforço de teorização consiste, ao menos em parte, em responder à questão fundamental: "o que ensinar?". Em sua preocupação com a questão epistemológica fundamental ("o que significa conhecer?"), Paulo Freire desenvolveu uma obra que tem implicações importantes para a teorização sobre currículo (Silva, 2011, p. 59).

Ao tratar da concepção curricular Freireana Torres (2010) e Autor e colaborador (2018) apontam que a transposição das ideias Freireanas para o contexto de educação formal é caracterizada por uma concepção curricular crítica, em que os objetos de estudo passam a ser não apenas o conceito científico, mas uma realidade a ser problematizada e transformada, justamente por meio dos Temas Geradores.

De acordo com Paniz e Muenchen (2020), o objetivo do Tema Gerador envolve proporcionar, com base nos conhecimentos já construídos pelos sujeitos, a possibilidade de (re)construção, a partir de diálogos coletivos. Através da compreensão da realidade que cada sujeito possui, é possível, pela problematização e pelo diálogo, ressignificar sua visão de mundo.

As premissas básicas de um Tema Gerador, portanto, giram em torno da ideia Freireana de sujeito-realidade, isto é, baseiam-se em como o sujeito lê sua própria realidade, ou mais do que simplesmente ler, em como ele interpreta o contexto real e se insere neste. Para Freire (1987), o papel educativo está em problematizar e desvelar estas interações sujeito-realidade, utilizando-se das chamadas situações-limite.

As Situações-Limites são, para Freire (1987), situações em que o sujeito deparase em determinada percepção e, inconsciente desta, não vê alternativa para superá-la, de modo que passa a introjetá-la, aceitando-a como natural, mesmo quando não o é. O conceito de Situação-Limite nasce, portanto, pelo fato do sujeito Homem ser um sujeito histórico, ser criativo, capaz de transformar, mas que, diante da ação consciente sobre $o$ mundo real, "enfrenta obstáculos que aparecem como freios na busca da conquista da 
mudança desejada" (Costa \& Furtado, p. 2, 2015). No mesmo sentido, para Gehlen (2009), uma "situação-limite" expressa uma contradição real e significativa de determinada comunidade de sujeitos, os quais, inacabados e inconscientes, não percebem como uma contradição, mas como certo "fatalismo", pré-concebendo tais situações como oriundas de "destino dado"; por isso a necessidade de haver uma investigação do real, do contexto da comunidade

Desta forma, o trabalho no viés Freireano, ou mais especificamente, com Temas Geradores, é uma possível forma de se repensar os currículos escolares, em uma visão crítica. Como se discutirá na sequência, esta análise só foi possível com a transposição da educação Freireana para o contexto de educação formal, pois foi onde ocorreu e estão a ocorrer mudanças estruturais. Sendo assim, no texto que segue são realizadas análises de como o trabalho com Temas Geradores foi ganhando destaque ao longo dos anos, fazendo com que Freire fosse sempre reinventado. Após tais discussões, são descritas algumas etapas metodológicas realizadas no âmbito deste estudo.

\section{Dos "espaços" aos "territórios": como nasce a perspectiva curricular Freireana?}

A origem da discussão curricular Freireana remete, obviamente, à obra de Paulo Freire e ao seu célebre livro Pedagogia do Oprimido. Especificamente no capítulo três, intitulado "A dialogicidade - essência da educação como prática da liberdade", Freire defende a ideia do diálogo como fator principal do processo educativo. Para o autor, “somente o diálogo, que implica um pensar crítico, é capaz também, de gerá-lo" (Freire, 1987, p. 83).

Por valorizar tanto a prática dialógica, seria antagônico se esta prática estivesse somente restrita ao trabalho em sala de aula. Por isso, para Freire, "o diálogo começa na busca do conteúdo programático", isto é, desde o momento em que é concebida a escolha do "o que trabalhar?".

À medida que foi sendo (re)conhecido, lido e reinventado, Freire - e sua obra começaram a ganhar espaço nos mais variados contextos. Um desses contextos remete a um grupo, muito específico, do Ensino de Ciências brasileiro. De acordo com Pierson (1997), o grupo "Reelaboração de Conteúdo e Formação de Professores", vinculado ao departamento de Física da Universidade de São Paulo, estava preocupado e intencionado em repensar o Ensino de Física e de Ciências, naquela época.

Ao analisar as ações deste coletivo, Pierson (1997) identificou que eles viam o "cotidiano" do educando de uma outra maneira, não como algo estático, mas como algo a ser problematizado e alterado. Segundo a autora, esta visão estava embebida das ideias Freireanas, de modo que:

O pensamento de Paulo Freire tem sido uma referência constante, dando uma direção que, se em alguns momentos é também metodológica, boa parte das vezes mostra-se não apenas enquanto o pensamento de um educador, mas a visão de mundo de um epistemólogo que, mesmo nunca tendo reconhecido-se como tal, 
não deixa de fornecer elementos sobre os quais pode-se fundamentar uma visão de conhecimento baseada na dialogicidade e problematização, pressupostos indispensáveis para a construção de um conhecimento emancipatório e conscientizador (Pierson, 1997, p. 154).

O grupo de "Reelaboração de Conteúdo e Formação de Professores", como o próprio nome sugere, intencionava repensar não só a forma de como preparar - "Formação" - mas o quê trabalhar - "Conteúdo". Do ponto de vista histórico, é de fundamental importância o depoimento de Demétrio Delizoicov, membro do grupo, à Revista Brasileira de Ensino de Física, em meados de 1980. Nesta entrevista, entende-se de forma mais clara o contexto da época e as intenções:

$\mathrm{Eu}$ acho que tudo começou, basicamente, em 1975. A gente formou aquele grupo, aqui dentro do Instituto, para tentar desenvolver uma certa linha em ensino de física. Dentro dessa linha, a gente julgava que o ensino de física devia ter uma relevância maior do que aquela de preparar o aluno para fazer o vestibular [...]. Enfim, os conceitos foram evoluindo, as ideias foram crescendo e se começou a estudar Paulo Freire. Percebemos certa identidade na premissa básica do método dele, com o que queríamos levar. Depois de sistematizar os estudos de Paulo Freire, restava fazer alguma coisa: foi aí que a "porca torce o rabo" (Delizoicov, 1980, p. 57).

Foi então, a partir desta posição, que - segundo relato do próprio professor Demétrio - , que ele partiu, juntamente com outros pesquisadores, em busca do sujeito Freire, para conhecê-lo melhor e para trabalhar nesta nova "certa linha de ensino de física", que Pierson (1997) vai chamar de "Abordagens Temáticas".

Como descrito por Delizoicov (1982), havia algo em comum entre o trabalho do grupo e a ideia de Tema Gerador Freireano, ao passo que se sentia certa "problemática" à adaptação de Freire ao contexto de educação formal em ciências.

Mesmo percebendo dificuldades nas adaptações curriculares Freireanas, o grupo estava convicto "que a educação problematizadora, poderia ser também levada ao âmbito da educação formal, e não só para adultos, mesmo considerando, que a nossa atuação, em princípio, estaria vinculada especificamente à educação em ciências" (Delizoicov, 1982, p. 50).

Assim sendo, ao irem trabalhar na Guiné-Bissau, tendo por base as intenções, leituras e contribuições construídas pelo coletivo, no Instituto de Física, Demétrio e seus colegas realizam um trabalho de formação de professores com base em ideais Freireanos (Muenchen, 2010). Sobre a proposição de Delizoicov (1982), portanto, destaca-se que se trata de uma primeira versão da aproximação de Freire para o contexto de educação formal. Ao escrever o livro Pedagogia do Oprimido, Freire explicita que os "conteúdos programáticos" devem derivar do mundo do educando e, para isso, pensa a busca pelos Temas Geradores a partir de quatro etapas: (a) levantamento preliminar; (b) codificação; (c) círculo de investigação temática; (d) redução temática. 
Ao realizar uma releitura da obra Freireana, pensando especialmente no campo curricular, Delizoicov (1982) propõe uma quinta etapa, posterior às anteriores: (e) trabalho em sala de aula.

A (re)leitura da perspectiva Freireana, sistematizada por Delizoicov (1982) ao contexto de educação formal, portanto, foi um primeiro e importante trabalho neste viés. Entretanto, as análises desenvolvidas pelo grupo, naquela época, assim como das derivadas daquele trabalho, sustentaram outras releituras deste Tema Gerador.

Sendo assim, percebe-se que as ideias Freireanas, as quais emergiram em espaços de educação não formal, começaram a ganhar outras (re)leituras, em outros espaços, articulando-se em outros processos, corporificando-se em territórios curriculares.

O desenvolvimento teórico da perspectiva curricular Freireana - dos Temas Geradores - não se fez distante do desenvolvimento prático, das salas de aula, dos sujeitos e profissionais da educação ${ }^{2}$. Por isso mesmo, as experiências ocorridas em São Paulo do Potengui (Pernambuco, 1994) e na cidade de São Paulo (São Paulo, 1992), possibilitaram a reinvenção da proposta dos Temas Geradores. Nestas experiências, por exemplo, houve o desenvolvimento da proposta dos Três Momentos Pedagógicos como estruturantes de currículos (Muenchen, 2010). Ademais, os Movimentos de Reorientações Curriculares desenvolvidos nos âmbitos de governos populares proporcionaram a construção e fortalecimento das Práxis Curriculares Via Tema Gerador (Silva, 2004) e ressignificaram a estrutura dos Temas.

A constituição da perspectiva curricular dos Temas Geradores, de espaços aos territórios, ocorreu por meio de tensionamentos, disputas e construções coletivas, tendo em vista, por exemplo, que a presença, ou não, de políticas públicas potencializam o trabalho nessa perspectiva: sejam políticas que propiciam currículos críticos ou que engessam em um currículo único e homogêneo (Saul, 2014). Distante de esgotar as discussões, provoca-se a pensar: nos tempos atuais, como se constituem os estudos curriculares Freireanos?

\section{Metodologia}

A construção curricular Freireana descrita nas páginas anteriores, por óbvio, não deve ser entendida como algo linear e livre de tensões. Optou-se por uma forma de escrita que privilegia ao leitor uma ampla - mas resumida - visão da origem e das reinvenções iniciais da pedagogia Freireana no campo de Ensino de Ciências.

A fim de compreender melhor os nuances associados a esta construção e disseminação de conhecimentos e práticas curriculares Freireanas, realizou-se uma revisão bibliográfica com base em materiais produzidos por sujeitos que circulam em eventos da área de Ensino de Ciências, visto que os trabalhos apresentados em eventos são desenvolvidos por diferentes sujeitos, desde graduandos até doutores.

2 Como forma de exemplificar a relação entre sujeitos, teoria e prática, faz-se lembrança à fala do professor Antônio Fernando Gouvêa da Silva, no painel de abertura do XII Encontro Nacional de Pesquisa em Educação em Ciências, quando ele diz que "foi todo um processo que, na realidade, me formou. Tanto a Marta, como o Demétrio, como o João me ensinaram a compreender aquilo que eu já lia a um bom tempo e tinha dificuldade de compreender". 
O objetivo central desta revisão foi entender e identificar os elementos, contextos e sujeitos considerados nos processos de obtenção/construção de Temas Geradores, ao longo dos últimos anos. Deste modo, conduziu-se o processo de busca por trabalhos em atas dos principais eventos da área de Ciências: Encontro Nacional de Pesquisa em Educação em Ciências (ENPEC), Simpósio Nacional de Ensino de Física (SNEF), Encontro Nacional de Ensino de Química (ENEQ) e Encontro Nacional de Ensino de Biologia (ENEBIO) e em dois dos principais eventos que versam sobre Freire: Fórum de Estudos e Leituras de Paulo Freire (FEL) e Seminário Nacional Diálogos com Paulo Freire (SNDPF).

Entende-se que tais eventos, por seus históricos e produções, constituem fontes importantes de consulta sobre o tema desta pesquisa, e possibilitam olhar para um espectro amplo de práticas e teorias desenvolvidas no contexto brasileiro ao longo de mais de duas décadas de produções. Assim como os eventos associados ao ensino de ciências (ENPEC, SNEF, ENEQ, ENEBIO), os eventos específicos de Paulo Freire são reconhecidos dentro da área e se constituem como um espaço de trocas, diálogos, construção e disseminação de conhecimentos, possuindo grandes historicidades e abarcando uma maior gama de sujeitos (Ingrassia, 2018),

Assume-se, de antemão, a dificuldade encontrada para reunir as atas, e por conseguinte os trabalhos, destes eventos. Apesar de o recorte inicial proposto ser deste o ano de 1997 até o ano de 2017 (vinte anos de pesquisa), nos eventos como os ENEQs e ENEBIOs, assim como nos específicos de Freire, não foram consideras todas as atas ${ }^{3}$.

A partir dos trabalhos disponíveis realizou-se uma busca utilizando como critério de seleção a palavra "Tema Gerador". Isto é, realizou-se uma primeira seleção, entre os trabalhos disponíveis, por produções que tivessem no corpo do texto (entenda-se todo o trabalho, do título às referências), o termo "Tema Gerador". O quantitativo de trabalhos considerados e selecionados, nesta primeira edição, são apontados na Tabela 1 , na sequência.

3 A dificuldade em reunir as atas dos ENEQs e ENEBIOs tentou ser superada ao solicitar os trabalhos para organizadores e outros colegas pesquisadores, mas, mesmo assim, houve negativas e/ou não se obteve respostas. Já em relação aos eventos específicos de Freire, as respostas obtidas por ex-organizadores e organizadores atuais foi que, infelizmente, não há um banco de dados organizado nas primeiras edições e, muito possivelmente, materiais se perderam. Deste modo, o espectro de trabalhos analisados em cada edição dos eventos correspondem aos anos de: (i) ENPEC: 1997, 1999, 2001, 2003, 2005, 2007, 2009, 2011, 2013, 2015 e 2017 (dez edições); (ii) SNEF: 1997, 1999, 2001, 2003, 2005, 2007, 2009, 2011, 2013, 2015 e 2017 (dez edições); (iii) ENEQ: 2004, 2006, 2008, 2010, 2012, 2014 e 2016 (sete edições); (iv) ENEBIO: 2008, 2010 e 2012 (três edições); (v) Fórum de Estudos e Leituras Paulo Freire: 2007, 2009, 2012, 2015 e 2017 (cinco edições); Seminário Nacional Diálogos com Paulo Freire: 2012, 2013 e 2016 (três edições). 
Tabela 1. Quantitativo geral de trabalhos selecionados na primeira análise

\begin{tabular}{|c|c|c|c|c|c|c|}
\hline \multirow[b]{2}{*}{ Evento } & \multirow{2}{*}{$\begin{array}{l}\text { Total de } \\
\text { trabalhos } \\
\text { considerados } \\
\text { (do evento) }\end{array}$} & \multirow{2}{*}{$\begin{array}{c}\mathrm{No}^{\circ} \mathrm{de} \\
\text { trabalhos } \\
\text { com } \\
\text { termo }\end{array}$} & \multirow{2}{*}{$\begin{array}{c}\text { No de } \\
\text { trabalhos } \\
\text { selecionados } \\
-1^{\mathrm{a}} \\
\text { Análise }\end{array}$} & \multicolumn{3}{|c|}{ No trabalhos não considerados } \\
\hline & & & & $\begin{array}{l}\text { Informação } \\
\text { insuficiente }\end{array}$ & $\begin{array}{c}\text { Outros } \\
\text { contextos }\end{array}$ & Referências \\
\hline SNDPF & 490 & 27 & 6 & - & 21 & - \\
\hline FEL & 1093 & 53 & 9 & 1 & 41 & 2 \\
\hline ENEBIO & 965 & 17 & 2 & 2 & 7 & 6 \\
\hline SNEF & 3721 & 47 & 14 & 3 & 29 & 1 \\
\hline ENEQ & 4237 & 181 & 63 & 49 & 46 & 23 \\
\hline ENPEC & 7440 & 205 & 54 & 13 & 128 & 10 \\
\hline $\begin{array}{l}\text { TOTAL } \\
\text { Fonte: autores }\end{array}$ & 17946 & 530 & 148 & & 382 & \\
\hline
\end{tabular}

A leitura da Tabela 1 possibilita identificar o quantitativo total de trabalhos considerados na análise, quantos destes possuíam o critério de seleção e, mesmo contendo a palavra-chave, quantos destes foram excluídos ( $n^{\circ}$ trabalhos não considerados) ou considerados para uma posterior análise ( ${ }^{\circ}$ trabalhos selecionados $-1^{\text {a }}$ Análise).

Do total de 17946 trabalhos, oriundos de todas as edições consideradas em todos os eventos, 530 possuíam a palavra "Tema Gerador", o que corresponde a 2,95\% do total analisado.

Após a separação destes 530 trabalhos, procedeu-se a (re)leitura dos títulos, resumos, palavras-chave e, separou-se, os trabalhos que apontavam e/ou discutiam "Tema Gerador" de modo mais recorrente, argumentativo, explicativo, tendo ele como um "eixo principal" da discussão realizada.

Assim sendo, a quarta coluna da Tabela 1 apresenta o quantitativo de trabalhos selecionados após esta primeira análise: dos 530 trabalhos com o termo, selecionouse 148, os quais traziam a discussão relativa à Temas Geradores de modo mais claro, explícito, não importando a definição dada pelos autores do trabalho ao termo "Tema Gerador".

Em relação as 530 produções com o termo, portanto, 27,92\% (148) foram préselecionados. O restante, aproximadamente $72 \%$ (382) foram desconsiderados por, basicamente, três motivos: por possuírem "informações insuficientes" (68 produções), pelo termo estar sendo usado em "outros contextos" (272 produções), e/ou pelo termo estar apenas nas "referências" dos trabalhos (42 produções).

Sendo assim, da primeira análise resultaram 148 produções, as quais utilizam Tema Gerador, de acordo com suas próprias convicções, aos seus modos, mas de forma mais sistemática, em que tal "conceito" está relacionado ao objetivo do presente artigo.

Não obstante, está-se claro que a literatura da área tem apontado certa confusão quanto ao uso do termo "Tema Gerador" (Schneider et al., 2015; Torres, 2010), de modo que, para Fonseca et al. (2015), 
[...] a expressão Tema Gerador tem sido utilizada em diversos contextos, assim, neste trabalho sinaliza-se para a importância de se considerar as especificidades do Tema Gerador baseado na perspectiva freireana. Embora Paulo Freire tenha conceituado o Tema Gerador ressaltando em suas discussões o processo de Investigação Temática, esse aspecto da sua proposta tem sido pouco abordado nas pesquisas acadêmicas em Educação em Ciências (Fonseca et al., 2015, p. 6).

A premissa apontada pelos autores da área permite reflexões quanto a estes 148 trabalhos selecionados na primeira análise. A cada nova (re)leitura, percebeu-se certa carência de uma definição de Tema Gerador, em algumas das produções, próxima à pedagogia Freireana. Mais do que uma definição, a inconsistência estava no fato da terminologia não apresentar discussões, elementos mínimos com base em referenciais Freireanos, quaisquer que fossem estes. A discussão sobre Tema Gerador estava embasada em argumentos rasos, definições próprias ou até mesmo sem nenhuma definição, apesar de haver - por parte dos autores - a confirmação de que trabalhavam com "Temas Geradores".

Por isso mesmo, ainda nesta discussão metodológica, realizou-se uma nova análise e uma separação quanto às proximidades e distanciamentos à perspectiva curricular Freireana. Tal separação considerou uma mínima menção a referenciais Freireanos, isto é, caso não houvesse referências mínimas, mas explícitas quanto ao "conteúdo freireano" do trabalho, seja no referencial teórico ou na discussão propriamente dita, este foi desconsiderado.

Desta maneira, com base nas justificativas elencadas, restaram 110 trabalhos derivados desta segunda análise. A Tabela 2 , na sequência, contém o número de trabalhos considerados e desconsiderados durante os processos de (re)leituras.

Tabela 2. Trabalhos selecionados na $2^{a}$ análise

\begin{tabular}{|c|c|c|c|}
\hline \multirow[b]{2}{*}{ Evento } & \multirow{2}{*}{$\begin{array}{l}\text { No de trabalhos } \\
\text { selecionados }-1^{\mathrm{a}} \\
\text { Análise }\end{array}$} & \multicolumn{2}{|c|}{$\mathrm{N}^{\circ}$ de trabalhos $-2^{\mathrm{a}}$ análise } \\
\hline & & $\begin{array}{l}\text { Baseiam-se na } \\
\text { epistemologia Freireana }\end{array}$ & $\begin{array}{c}\text { Não se baseiam na } \\
\text { epistemologia Freireana }\end{array}$ \\
\hline SNDPF & 6 & 6 & - \\
\hline FEL & 9 & 9 & - \\
\hline ENEBIOs & 2 & - & 2 \\
\hline SNEFs & 14 & 11 & 3 \\
\hline ENEQs & 63 & 40 & 23 \\
\hline ENPECs & 54 & 44 & 10 \\
\hline Total & 148 & 110 & 38 \\
\hline
\end{tabular}

Fonte: autores 
Tem-se a necessidade de pontuar, neste momento, o que está se compreendendo por "epistemologia Freireana", mesmo que elementos desta sejam abordadas no restante do texto. Tanto para a seleção dos trabalhos, como para a argumentação teórica subsequente, entende-se epistemologia Freireana como sendo o conjunto de conhecimentos e práticas que tenham por base o referencial de Freire ou de referenciais - textos e autores - que se utilizem a obra original Freireana com a intenção de reinventá-lo. Por isso mesmo, a epistemologia Freireana não se restringe ao "método Paulo Freire", ou ao teórico/homem Freire, mas a toda historicidade e teoriz(ação), derivada daquele. Em outras palavras 110 trabalhos referenciam o "Tema Gerador" e 38 trabalhos não o referenciam.

Assume-se que os 110 trabalhos selecionados possuem argumentos/conteúdos baseados em contributos Freireanos, que os credenciaram a serem objetos de estudo da pesquisa ${ }^{4}$. Torna-se fundamental destacar que a diversidade dos materiais potencializou as análises em diferentes direções (teórico/prático, pedagógico, curricular, epistemológico), de modo que eles foram explorados por meio Análises Cienciométricas e da Análise Textual Discursiva (ATD).

A Análise Cienciométrica, de acordo com Coutinho et al. (2012), envolve estudos quantitativos das atividades científicas, incluindo a publicação, possibilitando a construção de panoramas e políticas amplos. Por sua vez, a ATD, comumente utilizada em pesquisas de cunho qualitativo, caracteriza-se pelas investigações/análises rigorosas e criteriosas, almejando - como intenção primeira - a compreensão dos objetos de estudo a partir de novos emergentes, por meio das etapas de unitarização, categorização e comunicação (Moraes \& Galiazzi, 2007). Para que se pudesse desenvolver tais etapas, foram feitas diversas leituras na íntegra de todos os trabalhos, de modo que as análises (desconstrução/reconstrução) almejaram identificar sujeitos, contextos e elementos associados ao tema de pesquisa.

De todo, serão apresentados resultados acerca de alguns elementos e contextos associados à perspectiva curricular do Tema Gerador, derivados das análises dos trabalhos. Assim, tendo em vista o objetivo do trabalho, na sequência são apresentados e descritos resultados referentes à(s):

- Quais os contextos em que se estruturam as produções, advindas dos materiais? (via Análise Cienciométrica)

- Referências bibliográficas como elementos importantes para a disseminação de conhecimento (via Análise Cienciométrica)

- Como os trabalhos auxiliam na emersão de significados (elementos)? Resultando nas categorias (via Análise Textual Discursiva): (1) A valorização do conhecimento por meio da problematização e diálogo: os momentos pedagógicos; (2) Conhecer para transformar com base na contextualização e interdisciplinaridade

\footnotetext{
4 Por restrições de formatação, optou-se por não apresentar a lista completa dos 110 estudos selecionados. Ao final, apresenta-se o Apêndice com a identificação do título dos trabalhos os quais foram citados neste artigo. A lista completa dos trabalhos pode ser acessada em Magoga (2021). No decorrer do texto, as unidades de significados destes estudos - definidas via etapa da Análise Textual Discursiva — serão apresentadas com a seguinte estrutura "Evento_Ano_notrabalho_Unidade de significado"
} 


\section{Resultados e discussões}

Inicia-se a apresentação dos resultados a partir das Análises Cienciométricas. Após, realizam-se discussões derivadas da ATD.

\section{Quais os contextos em que se estruturam as produções, advindas dos materiais?}

Neste momento está-se interessado em destacar o contexto dos autores dos trabalhos, suas regiões, instituições e nomes. Ressalta-se, portanto, que se trata do contexto da produção do trabalho escrito (seja ele teórico e/ou prático), e não do local de determinada ação prática a qual pode estar descrita nos trabalhos.

Estas leituras possibilitaram perceber a região e a instituição dos autores de cada trabalho.

Neste sentido, a Figura 1 trata de um gráfico que mostra, com base nas informações dos autores de cada trabalho, locais de produção dos estudos relativos a Tema Gerador. Este foi elaborado observando a recorrência destas instituições em cada trabalho, caracterizando-se como um levantamento cienciométrico.

Figura 1. Gráfico das instituições em que se produzem os trabalhos

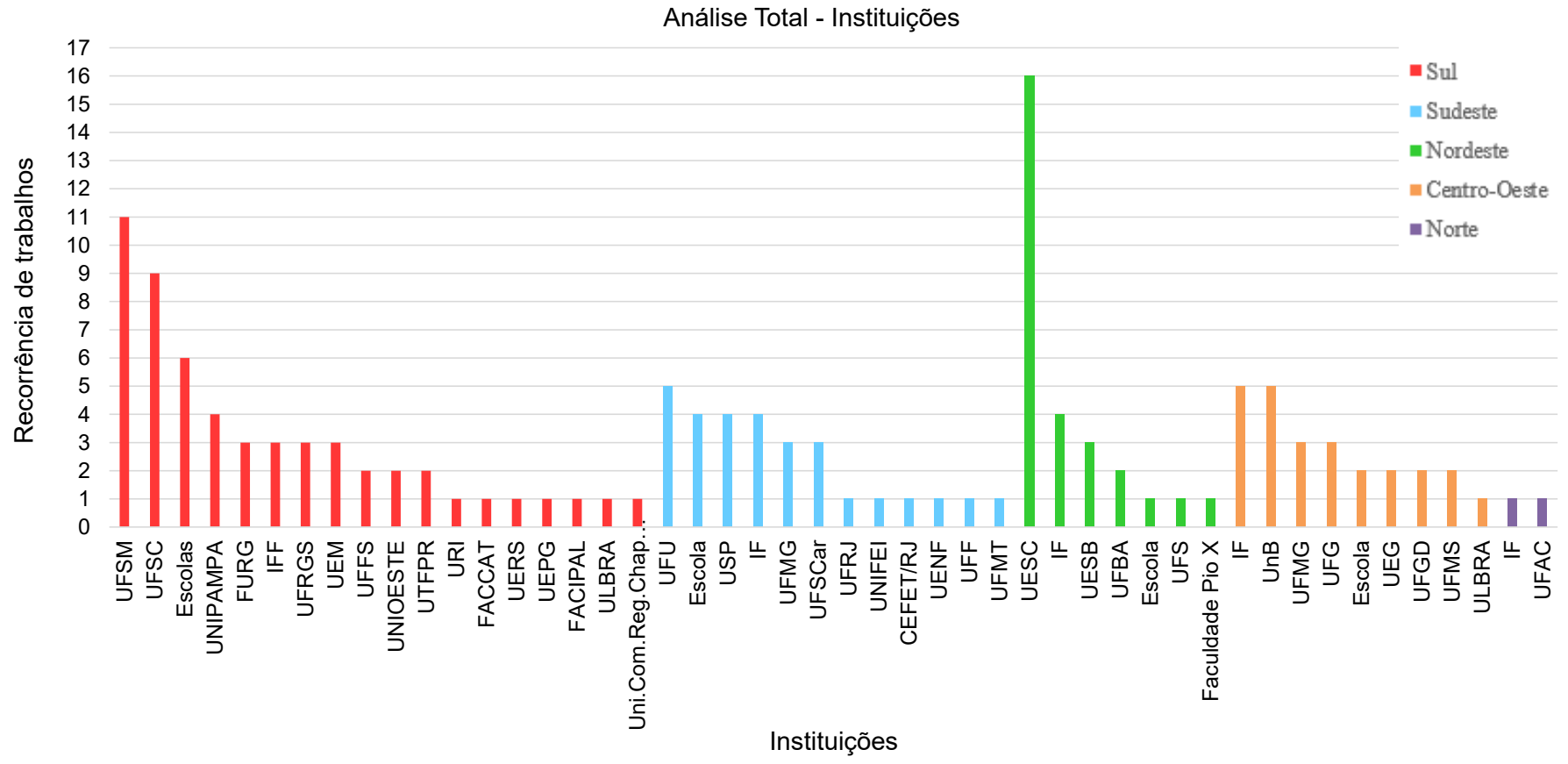

Fonte: autores.

A Figura 1, portanto, mostra em quais espaços/instituições tem-se escrito de maneira mais recorrente sobre Temas Geradores, em cada região do Brasil. Com base na leitura da figura, obtêm-se importantes resultados quanto ao contexto de produção 
sobre a temática ${ }^{5}$. Observa-se que os principais locais de produção de conhecimento relativos a Tema Gerador são três universidades públicas: UFSM (Universidade Federal de Santa Maria (com onze trabalhos), a Universidade Federal de Santa Catarina (UFSC) (com nove trabalhos) e a Universidade Estadual de Santa Cruz (UESC), da Bahia. A UESC, aliás, é a instituição que mais tem produzido trabalhos neste viés: dezesseis trabalhos foram produzidos por autores logrados na UESC, configurando-se como um importante centro de produção de conhecimento Freireano.

Salienta-se como um resultado importante o fato dos trabalhos desenvolvidos na UFSM e UESC serem, basicamente, de sujeitos pertencentes a dois grupos de pesquisas: o Grupo de Estudos sobre Abordagem Temática no Ensino de Ciências (GEATEC), locado na UESC; e o Grupo de Estudos e Pesquisas Educação em Ciências em Diálogo (GEPECiD). Incita-se a pensar que tais coletivos se constituem como espaços-tempo de produção de conhecimento curricular Freireano.

\section{Referências bibliográficas como elementos importantes para a disseminação de conhecimento}

Além dos lócus de produção de conhecimento curricular Freireano, informações importantes podem ser obtidas e analisadas a partir da lista de referências dos trabalhos selecionados, seja em termos de autores/sujeitos, ou em obras/elementos que ajudam na disseminação do conhecimento. Justifica-se a defesa de que as referências bibliográficas são importantes pois se entende que a partir da leitura, releitura, escrita e análises que se constroem conhecimentos. Observar o que mais é referenciado significa observar o que é mais é lido e, portanto, possibilita compreender quais elementos (obras) potencializam a disseminação do conhecimento, neste sentido. Em outras palavras: quem quiser iniciar o estudo envolvendo currículos Freireanos deve ler que obra(s)? Deve se apropriar de quais autores(as)?

Dessa forma, observou-se a recorrência de autores e obras em todos os estudos do corpus. Torna-se importante salientar, entretanto, que não foram consideradas referências associadas a documentos oficiais (a exemplo da LDB, Parâmetros), nem àquelas relativas às questões metodológicas (em que apareciam autores como, por exemplo, Bardin, Chizzotti, Moraes e Galiazzi, Porlán).

O primeiro aspecto a apontar está associado ao fato de, em todos os eventos, haver um revezamento entre o primeiro e segundo autores mais citados, sendo estes Paulo Freire (184 vezes) e Demétrio Delizoicov (159 vezes). À exceção dos Simpósios Nacionais de Ensino de Física, em que Delizoicov (25 vezes) foi o autor mais referenciado, em todos os outros Freire é o mais utilizado (FEL e SNDPF: 44; ENEQ: 59; ENPEC: 61), tendo Delizoicov em segundo lugar (FEL e SNDPF: 15; ENEQ: 25; ENPEC: 59). Tal constatação deve estar associada, primeiro, pelos Temas Geradores - objeto de estudo

5 Incita-se a pensar não apenas onde mais e produz sobre Tema Gerador mas, também, porque há regiões em que essa produção é baixa, como no Norte. Uma hipótese, a qual se sugere investigação, pode estar associada às dificuldades de deslocamento das pessoas destas regiões (tanto financeiras como de translado). Pode-se pensar, portanto, na existência de um certo racismo educacional, em que sujeitos são privados de participarem de processos educativos. 
- ser característico Freireano e, segundo, por Demétrio Delizoicov ser um dos principais disseminadores da proposta Freireana, tendo escrito diversas releituras e participado na formação de diferentes sujeitos.

Deste modo, ao realizar tal observação, verificou-se que os autores citados comuns a todos os eventos foram: José Angotti, Décio Auler, Demétrio Delizoicov, Paulo Freire, Simoni Gehlen, Otávio Maldaner, Cristiane Muenchen, Marta Pernambuco e Antônio Gouvêa da Silva. Estes, portanto, parecem ser as principais referências Freireanas, na área.

Não obstante à análise dos nomes mais referenciados, pode-se construir uma discussão a partir das obras mais citadas, observando estas como importantes elementos para a disseminação e extensão do conhecimento Freireano.

As Tabelas 3, 4, 5 e 6 contém informações sobre os eventos, as obras mais referenciadas em trabalhos destes eventos e o respectivo número de recorrências.

Tabela 3. Obras mais referenciadas nos FELs e SNPFs

FELs E SNPFs

\begin{tabular}{cl}
\hline No recorrência & Referência (Autor) \\
\hline 15 & Pedagogia do Oprimido (Freire) \\
\hline 6 & Pedagogia da Esperança (Freire) \\
\hline 5 & $\begin{array}{l}\text { Educação como prática da liberdade } \\
\text { (Freire) }\end{array}$ \\
\hline 5 & A importância do ato de ler (Freire) \\
\hline 4 & $\begin{array}{l}\text { Conhecimento, tensões e transições } \\
\text { (Delizoicov) }\end{array}$ \\
\hline 4 & $\begin{array}{l}\text { Ensino de Ciências: fundamentos } \\
\text { e métodos (Delizoicov, Angotti e } \\
\text { Pernambuco) }\end{array}$
\end{tabular}

Fonte: autores

Tabela 4. Obras mais referenciadas nos SNEFs

\begin{tabular}{cl}
\hline \multicolumn{1}{c}{ SNEFs } \\
\hline No recorrência $^{\text {Referência (Autor) }}$ \\
\hline 11 & Pedagogia do Oprimido (Freire) \\
\hline 8 & $\begin{array}{l}\text { Ensino de Ciências: fundamentos e métodos } \\
\text { (Delizoicov, Angotti e Pernambuco) }\end{array}$ \\
\hline 5 & $\begin{array}{l}\text { Conhecimentos, tensões e transições } \\
\text { (Delizoicov) }\end{array}$ \\
\hline 4 & $\begin{array}{l}\text { Abordagem temática freireana e o ensino de } \\
\text { ciências por investigação (Solino) }\end{array}$ \\
\hline 3 & $\begin{array}{l}\text { A construção do currículo na perspectiva } \\
\text { popular crítica (Silva) }\end{array}$
\end{tabular}

Fonte: autores 
Tabela 5. Obras mais referenciadas nos ENEQs

\begin{tabular}{cl}
\multicolumn{1}{c}{ ENEQs } \\
\hline No recorrência $^{\text {Referência (Autor) }}$ \\
\hline 11 & $\begin{array}{l}\text { Ensino de Ciências: fundamentos e métodos (Delizoicov, } \\
\text { Angotti e Pernambuco) }\end{array}$ \\
\hline 4 & $\begin{array}{l}\text { Educação em química: compromisso com a cidadania } \\
\text { (Santos e Schnetzler) }\end{array}$ \\
\hline 4 & $\begin{array}{l}\text { Metodologia do ensino de ciências (Delizoicov e } \\
\text { Angotti) }\end{array}$ \\
\hline 3 & $\begin{array}{l}\text { Concepção problematizadora do ensino de ciências na } \\
\text { educação formal (Delizoicov) }\end{array}$
\end{tabular}

Fonte: autores

Tabela 6. Obras mais referenciadas nos ENPECs

\begin{tabular}{cl}
\multicolumn{1}{c}{ ENPECs } \\
\hline No recorrência $^{\text {Referência (Autor) }}$ \\
\hline 35 & Pedagogia do oprimido (Freire) \\
\hline 24 & $\begin{array}{l}\text { Ensino de ciências: fundamentos e métodos } \\
\text { (Delizoicov, Angotti e Pernambuco) }\end{array}$ \\
\hline 18 & $\begin{array}{l}\text { A construção do currículo na perspectiva } \\
\text { popular crítica (Silva) }\end{array}$ \\
\hline 10 & Pedagogia da Autonomia (Freire) \\
\hline 7 & $\begin{array}{l}\text { Conhecimentos, tensões e transições } \\
\text { (Delizoicov) }\end{array}$
\end{tabular}

Fonte: autores

Observa-se que as obras mais referenciadas, por evento, são Pedagogia do Oprimido (FEL, SNPF, SNEF e ENPEC) e Ensino de Ciências: fundamentos e métodos (ENEQ). Não obstante, ao se analisar o número de recorrência total, em todos os eventos, a distribuição de obras referenciadas é descrita de acordo com a Tabela 7:

Tabela 7. Obras mais referenciadas em todos os eventos

\begin{tabular}{lll} 
Obra & Autor(es) & No de recorrências \\
\hline Pedagogia do Oprimido & Freire & 61 \\
\hline Ensino de Ciências fundamentos e métodos & $\begin{array}{l}\text { Delizoicov, Angotti e } \\
\text { Pernambuco }\end{array}$ & 47 \\
\hline A construção do currículo na perspectiva curricular crítica & Silva & 21 \\
\hline Conhecimentos, tensões e transições & Delizoicov & 16
\end{tabular}

Fonte: autores 
Como se pode perceber na Tabela 7, a obra Pedagogia do Oprimido é, disparada, a mais citada pelos trabalhos selecionados. Em tal, como já descrito no referencial, Freire apresenta as premissas de um Tema Gerador que, na área de Ensino de Ciências, é materializado através dos currículos escolares.

A reinterpretação do Tema Gerador é discutida no livro "Ensino de Ciências: fundamentos e métodos", especificamente no capítulo III "Aluno, conhecimentos escolares e não escolares". Na seção "Instrumentação para o Ensino", os autores do livro (Delizoicov, Angotti e Pernambuco) citam a obra Pedagogia do Oprimido:

As práticas pedagógicas cuja referência é o tema gerador têm suas bases teóricas na pedagogia de Paulo Freire e como fonte principal o clássico Pedagogia do Oprimido, sendo uma de suas sistematizações elaboradas pela equipe que coordenou o Movimento de Reorientação Curricular no Município de São Paulo, na década de 90 (Delizoicov et al., 2011, p. 165).

Ademais, na obra supracitada faz-se uma apresentação da concepção de Tema Gerador e, mais do que isso, sugere-se outra referência, como transcrito:

Os temas geradores organizam-se em três momentos pedagógicos (Delizoicov, 1991): estudo da realidade (ER), organização do conhecimento (OC) e aplicação do conhecimento (AC), cujos aspectos epistemológicos, educativos e didáticopedagógicos que os fundamentam serão apresentados na $4^{\mathrm{a}}$ Parte (Delizoicov et al., 2011, pp. 166-167).

Percebe-se, com isso, que a obra "Ensino de Ciências: fundamentos e métodos" tem importante valor epistemológico não apenas por ser uma das mais referenciadas nos trabalhos analisados, mas também por apresentar uma releitura da perspectiva curricular Freireana e ser importante fonte de outras referências como a tese de Demétrio Delizoicov, "Conhecimentos, tensões e transições", assim como o próprio livro Pedagogia do Oprimido, de Freire. Ressalta-se a importância deste resultado tendo em vista que o livro de Delizoicov, Angotti e Pernambuco é um material paradidático mais acessível aos educadores das escolas básicas do que, certamente, a tese de Delizoicov e, possivelmente, a obra de Freire.

Soma-se aos apontamentos dos parágrafos anteriores o fato desta obra paradidática ter sido a única referência comum (com mais de uma citação) a todos os eventos. Isto é, em cada evento, pelo menos dois trabalhos referenciaram tal livro.

\section{Como os trabalhos auxiliam na emersão de significados?}

Objetivando compreender elementos associados à disseminação das propostas de Temas Geradores, de um ponto de vista histórico, e, principalmente curricular e pedagógico, realizou-se a desconstrução de todos os 110 trabalhos. Via ATD, agruparamse unidades de significados semelhantes e realizou-se a captação do "novo emergente". Desta análise, portanto, emergiram as categorias discutidas na sequência. 


\section{A valorização do conhecimento por meio da problematização e diálogo: os momentos pedagógicos}

Se há algo central na pedagogia Freireana, trata-se da díade "problematização e diálogo" (Magoga \& Muenchen, 2018). Estes são indissociáveis e possuem características marcantes, não sendo entendidos como algo raso, desconexo dos sujeitos e contextos que os utilizam.

Diferentes podem ser as perspectivas educacionais em que o "dialogar" ganha destaque, mas o que distingue este "dialogar" do diálogo Freireano, portanto, é o papel indissociável entre ele, a problematização e o conhecimento, de modo que não se trata de "um mero blá-blá-blá, mas um diálogo que, respeitando os educandos, auxilie na problematização em torno de um olhar crítico do mundo e de seu contexto" (Autor, 2017, p. 40). Não obstante, como apontado pelo trabalho SNEF_2013_4

[...] não cabe ao professor apenas dialogar. Quando se trabalha com temas numa perspectiva freiriana, é necessário tornar o aluno crítico e pensante. Assim, é necessário haver o diálogo problematizador (SNEF_2013_4_7).

O adjetivo dado ao diálogo pelo trabalho SNEF_2013_4 vai ao encontro da premissa construída nos últimos parágrafos, pois qualifica-o, apontando como problematizador, como Freireano, e possibilita perceber em torno do que gira esta categoria.

Durante as recorrentes leituras, percebeu-se que os trabalhos destacavam a importância do conhecimento do aluno, às vezes denominado educando, por vezes chamado de sujeito. A valorização ao conhecimento deste sujeito - indiferente se este era professor da educação básica, pós-graduando, licenciando ou aluno da educação básica —, na visão dos autores dos trabalhos, faz com que a ação formativa ganhe sentido, pois "é perceptível que os saberes populares não devem ser descartados, uma vez que podem favorecer o entendimento dos conceitos científicos" (ENEQ_2016_16_4).

Em certo aspecto, esta defesa vai ao encontro do que colocam Delizoicov et al. (2011): de que a prática educativa deve ser proposta a partir da cultura primeira, transformando-se em uma cultura elaborada. Por isso, "reconhecer que o aluno já chega à sala de aula com sua própria leitura sobre o mundo e valorizar sua curiosidade natural sobre as coisas do seu cotidiano pode possibilitar uma melhor significação dos conceitos científicos" (ENEQ_2016_21_1).

Como apresentado nos parágrafos anteriores, a valorização deste conhecimento prévio dá-se não apenas pela escuta do que os educandos têm a dizer, mas principalmente pela problematização disto, via processo dialógico, pois

O tema gerador, consiste na problematização da prática de vida dos educandos. Utiliza-se uma metodologia dialógica, onde os conteúdos disponíveis, por mais rudimentares que sejam, serão fruto de investigação e permeabilizarão a ação pedagógica (ENEQ_2014_23_1). 
O reconhecimento de que o educando não é um "vasilhame vazio" em que são depositados saberes, conhecimentos, é anunciado por Freire (1987), quando ele constrói as premissas para a investigação de um Tema Gerador. Parece, portanto, que estas características ainda têm sido presente na perspectiva curricular Freireana atual.

Destaca-se que Freire (1987), apesar de tratar do diálogo e da problematização como essenciais à prática educativa, defende-os como articuladores necessários para a obtenção dos Temas Geradores; isto é, coloca-os em destaque já durante a busca do conteúdo programático. Algo próximo ao descrito por FEL_2015_8:

usando a investigação temática para obtenção de temas geradores no contexto escolar, realizamos as etapas da investigação temática de Freire (2005), que se destaca na importância da utilização do diálogo e problematização como forma de obtenção de temas geradores e devolvendo como uma concepção dialógicoproblematizadora da educação (FEL_2015_8_1).

$\mathrm{Na}$ argumentação que se está a construir, os elementos desta categoria sustentam também as práticas de sala de aula, visando a superação do que se denominou de conhecimento prévio. Apresenta-se, como forma de iluminar tais argumentos, outra unidade de significado.

$\mathrm{Na}$ pesquisa desenvolvida aspectos relacionados ao desenvolvimento de percepção crítica da realidade em prática dialógica apontam para a importância da prática problematizadora na construção e vivência da cidadania a partir da discussão de conhecimentos físicos (SNEF_2009_2_5).

Indiferente do momento, ou da forma com que são utilizados, constata-se que o diálogo e a problematização são características que, segundo os estudos, estão intrínsecas ao Tema Gerador. Porém, para a discussão desta categoria, interessa frisar a defesa dos autores da presença destes momentos na perspectiva curricular.

Identificou-se que a valorização do conhecimento do aluno, por meio da problematização e diálogo tem se desenvolvido, nos contextos formativos, de uma maneira muito peculiar: através dos Três Momentos Pedagógicos (3MP), como metodologia de trabalho.

A discussão dos $3 \mathrm{MP}$ é realizada por distintos autores, como mencionado anteriormente. Entretanto, considerando que o livro "Ensino de Ciências: fundamentos e métodos" foi a obra mais recorrente nas análises cienciométricas realizadas, centra-se nesta para a discussão dos momentos.

De acordo com Delizoicov et al. (2011), os 3MP são uma forma de construir prática educativas com base nas premissas Freireanas, e são organizados a partir da (i) problematização inicial; (ii) organização do conhecimento; (iii) aplicação do conhecimento.

De modo geral, a maioria dos trabalhos considerados que utilizam os 3MP não tem a pretensão de explorá-los em suas análises. Limitam-se, basicamente, a apontá-los como essenciais e/ou como a forma com que se desenvolveu as ações. Exemplos disto são apontados, na sequência: 
[...] explicita-se a organização de um curso de formação continuada de professores de Ciências focalizado na obtenção de Temas Geradores e na elaboração de atividades didático-pedagógicas, tendo como referência a dinâmica dos Momentos Pedagógicos (SNEF_2015_8_1).

As aulas foram implementadas pela pesquisadora no período de maio a junho de 2012, juntamente com o Grupo de Estudos sobre Abordagem Temática no Ensino de Ciências (GEATEC) da Universidade Estadual de Santa Cruz (UESC) e estruturadas com base nos Momentos Pedagógicos (ENPEC_2013_12_2).

Independente do contexto - se no contexto de formação de professores, como descrito nas unidades acima, ou na educação básica, com estudantes -, de acordo com Pernambuco (2002) "os momentos pedagógicos são um dos organizadores utilizados para garantir uma prática sistemática do diálogo", algo identificado e discutido nos parágrafos anteriores. Muenchen e Delizoicov (2014) ao realizarem um estudo sobre as transformações ocorridas nos 3MP ao longo dos anos, acrescentam que "a participação do estudante e o seu cotidiano assumem um papel de destaque na prática educativa que utiliza os $3 \mathrm{MP}$, proporcionando, à educação, um avanço no que se refere ao ensino tradicional" (p. 633).

Esta característica, entendida como potencialidade, é aliás, identificada e utilizada como justificativa nos estudos analisados, pois a utilização dos 3MP como ferramenta metodológica, vinculada ao trabalho com Temas Geradores, possibilita melhor aprendizagem.

Neste sentido, a aula planejada por meio dos Três Momentos Pedagógicos, além de permitir a relação entre conceitos de Física, Química e Biologia, mostrouse um potencial para o desenvolvimento de uma visão crítica dos educandos [...] Vale destaca que a relação estabelecida entre os Momentos pedagógicos e a Investigação Temática, foi incorporada nesse curso no sentido de potencializar o desenvolvimento da proposta, haja visto, que essa dinâmica possui estreita relação com a dialogicidade e problematização do conhecimento, aspectos fundamentais na proposta freireana (SNEF_2017_5_10).

[...] acredita-se que a exploração sistemática desse tema sob a metodologia dos Três Momentos Pedagógicos, propostos por Delizoicov e Angotti (1991, 2000), seja possível desenvolver um trabalho que promova uma aprendizagem significativa para o público da EJA (ENPEC_2017_8_1).

Ocorre que, apesar dos 3MP serem uma importante metodologia de sala de aula e garantirem a problematização e o diálogo de forma sistemática, como apontado pelos referenciais acima, o endossamento à utilização destes apenas como dinâmica metodológica pode passar a impressão de certa ignávia, tendo em vista todo o histórico de transformações dos momentos e de suas potencialidades como estruturantes de currículos. Por isso mesmo, entende-se que o papel dos momentos pedagógicos é maior 
do que apenas para uso em sala de aula, e pesquisas recentes mostram que estes têm sido utilizados de maneira mais recorrentes em outros contextos, como os curriculares (Watanabe, 2019).

Fato é, entretanto, que os 3MP — com suas características e objetivos - tem sido recorrentes nas ações educativas baseadas em Temas Geradores. Seja por potencializar a aprendizagem, seja para aproximar conceitos de temas, para fomentar diálogos, valorizar conhecimentos. Esta dinâmica pedagógica tem relacionado conhecimentos prévios, Tema Gerador, e conceitos científicos.

\section{Conhecer para transformar com base na contextualização e interdisciplinaridade}

Esta categoria apresenta argumentos que sinalizam elementos considerados para a realização da prática educativa, no contexto curricular dos Temas Geradores. Mais do que utilizar um Tema Gerador de maneira dialógica e problematizadora, as ações desenvolvidas possibilitaram a identificação de outras características, as quais encontram amparo exatamente em determinada concepção curricular.

A primeira destas características também forma a base constituinte de todo e qualquer Tema Gerador, ou generalizando, da perspectiva Freireana. Trata-se da necessidade e importância de investigar, analisar, conhecer a realidade dos educandos, tendo nesta um ponto de partida para a obtenção e construção dos Temas Geradores. Para o trabalho FEL_2017_6, "trabalhar na perspectiva de Temas Geradores possibilita valorizar a realidade na qual os educandos estão inseridos, bem como problematizá-la para pensar ações para modificá-la" (FEL_2017_6_1).

Percebe-se que os autores acima — assim como em outros trabalhos —, não se restringem apenas ao "conhecer" a realidade, mas ir além, como propunha Freire. Gadotti (2000), ao tratar sobre as perspectivas atuais da educação, também faz um alerta sobre este "conhecer". Não se trata apenas de conhecer uma realidade e dialogar dela, é imprescindível dialogar sobre ela, questioná-la, fazê-la passar para algo maior.

Em vista disto, emerge um conceito Freireano fundamental na composição da categoria, o de transformação, apontada pelos estudos como sendo um dos seus objetivos principais. Como forma de exemplificar tal discussão, aponta-se a unidade de significado abaixo. Ela se torna representativa na medida em que relaciona o "conhecer a realidade", em vista de sua "transformação", apontando que isto se faz em torno dos conhecimentos científicos, definidos pelos educadores com base na realidade.

Quando se discute uma perspectiva de educação problematizadora, ao contrário do que pode parecer a alguns, não se propõe o esvaziamento de conteúdos da escola, nem se considera que o trabalho com a realidade vai restringir o sujeito ao senso comum. Nesse sentido a realidade, ao servir como ponto de partida, vai oportunizar a explicitação de conceitos e contribuir para a aprendizagem e para a mobilização dos conhecimentos historicamente construídos. A seleção dos conteúdos, então, se constitui em tarefa permanente dos educadores, a partir do 
conhecimento da realidade dos estudantes e dos conhecimentos científicos que cada área pode mobilizar para ajudar a compreender e a transformar a realidade (ENPEC_2017_42_3).

Dando continuidade na construção desta categoria, portanto, dois outros importantes elementos são apontados como essenciais no trabalho educativo e, portanto, com temas geradores, os quais estão relacionados também ao papel dos educadores. São estes: a interdisciplinaridade e contextualização. Destaca-se que ambos giram em torno do Tema Gerador Freireano, sendo consideradas, portanto, como características Freireanas, de acordo com as defesas de Delizoicov e Zanetic (2002).

O conhecer a realidade, almejando transformá-la perpassa, obviamente, pela construção de um trabalho o qual se identificou como contextualizado pois:

Na Abordagem Temática Freireana, a contextualização perpassa todo o processo didático pedagógico, uma vez que os problemas locais vivenciados pelos estudantes e sintetizados no Tema Gerador são os que vão direcionar a contextualização no seu sentido social (ENPEC_2013_12_5).

Ao invés de contextualizar conceitos, com base na realidade, o trabalho com Tema Gerador objetiva contextualizar a realidade, utilizando dos conceitos, com o intuito de problematizá-la e transformá-la. A contextualização Freireana, portanto, distingue-se de outros modos de contextualizar porque esta última não se interessa em apenas olhar o cotidiano como algo estático, mas como passível de mudança.

Torna-se necessário realizar tal apontamento tendo em vista que os trabalhos (selecionados para esta análise, e até mesmo outros teóricos, da área), identificam tal característica, mas não realizam uma explanação tão aprofundada, o que pode causar, por vezes, certo estranhamento a outros sujeitos, viabilizando a equiparação de algo antagônico: "contextualizar Freireano" e "contextualização de conceitos".

Ainda tratando do contextualizar Freireano, pontuam-se outras duas unidades de significado:

Essa proposta de Paulo Freire leva-nos ao entendimento da contextualização, esquematizada na figura a seguir: problematizar a realidade; buscar a modelização, as teorias para compreendê-la; e retornar à realidade, de posse, agora, de uma maior bagagem de conhecimentos para poder ressignificá-la (ENEQ_2008_3_4).

Desta forma, defende-se aqui, a utilização de Temas Geradores como possibilidade para que os conteúdos sejam desenvolvidos partindo do local para o global, no sentido de contextualizar e dar sentido aos conhecimentos construídos pelos educandos (FEL_2017_6_3).

Ao tratar sobre os conhecimentos, outro elemento - entendido por alguns autores como processo (Centa \& Muenchen, 2016) —, ganha destaque: trata-se da interdisciplinaridade. Observou-se que a maioria dos estudos selecionados identifica grande relação entre Temas Geradores Freireanos e o trabalho interdisciplinar, a exemplo de SNPF_2016_5 e ENPEC_2017_4: 
O trabalho com o tema gerador é um trabalho interdisciplinar não apenas por envolver na sua busca diferentes áreas do conhecimento (Freire, 1987), mas por serem eles problematizados sob diferentes visões, o que torna sua investigação tanto mais pedagógica quanto mais crítica, fugindo das visões focalistas e buscando a compreensão da totalidade (SNPF_2016_5_2).

Além disso, este Tema Gerador também potencializa a interdisciplinaridade, visto que pode contemplar todos os componentes curriculares (ENPEC_2017_4_8).

O caráter interdisciplinar Freireano é percebido desde a busca dos Temas Geradores na etapa de levantamento preliminar, em que podem participar profissionais que não necessariamente sejam educadores, mas também psicólogos, sociólogos, entre outros (Freire, 1987).

Esta concepção de planejamento entre distintos sujeitos é balizada tendo em vista a própria natureza do Tema Gerador e de como este pode ser pensado/estruturado. Auler et al. (2009), ao realizarem uma análise da natureza dos temas, apontam esta relação como indissociável - entre Tema Gerador e interdisciplinaridade - e sinalizam que o trabalho coletivo na escola é fundamental para o enfrentamento dos problemas, dos dilemas vividos pela comunidade, e que são abarcados nos temas.

Ainda tratando sobre este tema, Frigotto (2008) descreve que "[...] a condição prévia para o trabalho interdisciplinar, tanto no nível da pesquisa como do trabalho pedagógico, é de que as concepções de realidade, conhecimento e os pressupostos e categorias de análise sejam criticamente explicitados" (pp. 47-48). Por isso mesmo, na construção desta categoria, observou-se que

A interdisciplinaridade é compreendida como a forma de trabalhar com os estudantes em sala de aula, em que se abrangem as diferentes disciplinas através de temas obtidos através da investigação temática, sendo trabalhados conjuntamente com as diferentes áreas do conhecimento, mas com cada professor trabalhando na sua área os conhecimentos necessários para o entendimento do tema (FEL_2015_8_8)

Ancorado por temas [geradores], a partir dos quais o conteúdo programático é selecionado, o currículo permite uma maior interdisciplinaridade entre as matérias escolares. Todas, a partir de sua especificidade, voltadas para a compreensão de um fenômeno (ENPEC_2017_27_1).

A concepção interdisciplinar Freireana, exemplificadas nas unidades acima, também resgata o sentido de cada disciplina, caracterizando-as de acordo com suas próprias estruturações epistemológicas

Partindo das características apontadas nesta categoria, de que o conhecer para transformar perpassa por um trabalho via Tema Gerador contextualizado e interdisciplinar, problematiza-se a essência desta intenção. Aproximando esta ideia ao contexto educacional brasileiro atual, em que grupos hegemônicos regem as discussões 
curriculares, tem-se certas dúvidas à possibilidade destes elementos Freireanos serem desenvolvidos. Provoca-se: será que a composição de uma BNCC não infertilizará ou podará novas ações Freireanas? Como os sujeitos os quais trabalham com a perspectiva curricular Freireana têm percebido esta questão? Qual o horizonte está-se a observar? Malheiros e Forner (2020) colocam como urgente a necessidade de pensar abordagens que possibilitem sulear as práticas educativas, as quais contribuam para o rompimento de um modelo proposto pela BNCC, em prol de um modelo crítico-emancipatório. Em outras palavras, para os autores, é fundamental que educadores e educadoras tenham consciência de seus papeis enquanto seres inacabados e a serviço de que(m) está este documento.

\section{Conclusões e Implicações}

Muito se produziu no campo curricular Freireano, no Ensino de Ciências. Tais produções possibilitam, portanto, resgatar o legado de Freireanas e Freireanos e delinear novos conhecimentos e práticas. Neste estudo, objetivou-se sinalizar alguns elementos e contextos fundamentais para a construção e disseminação do conhecimento acerca dos Temas Geradores.

Por meio de uma revisão bibliográfica nos principais eventos da área de Ciências e em eventos específicos de Freire, obteve-se resultados e teceram-se análises sobre os lócus de produção de conhecimento com base em Freire e, também, sobre a constituição das práticas curriculares.

A partir da Figura 1, constataram-se vários nomes de instituições nas quais se produzem trabalhos com a temática Freireana. Destacaram-se, entretanto, as três principais: Universidade Estadual de Santa Cruz (BA), Universidade Federal de Santa Maria(RS) e Universidade Federal de Santa Catarina (SC). Tais universidades constituemse como centros de formação na perspectiva curricular Freireana, de modo que parecem existir determinados grupos/coletivos residentes nestes locais. Exemplifica-se, neste momento, o Grupo de Estudos sobre Abordagem Temática no Ensino de Ciências (GEATEC), locado na UESC; e o Grupo de Estudos e Pesquisas Educação em Ciências em Diálogo (GEPECiD), locado na UFSM ${ }^{6}$.

Além dos espaços e coletivos (contextos), discutiu-se sobre alguns elementos associados à disseminação do pensamento Freireano. Observaram-se as obras mais referenciadas nos trabalhos, sobressaindo como as duas mais recorrentes, nesta ordem: Pedagogia do Oprimido (de Freire); Ensino de ciências: fundamentos e métodos (de Delizoicov, Angotti e Pernambuco).

Ademais, apontou-se que, dentre as obras mais recorrentes, a comum em todos os eventos analisados foi "Ensino de ciências: fundamentos e métodos". A recorrência da obra "Ensino de ciências", aliada ao conteúdo do livro, constituindo-se de extrema significância para a extensão do conhecimento Freireano. Reitera-se que a importância de

6 Tanto o GEATEC quanto o GEPECiD têm se constituído como importantes espaços interdisciplinares de produção de conhecimento Freireano, de modo que se compartilha e se convida a acessar os sites destes grupos: https://geatecuesc8.wixsite.com/geatec e https://sites.google.com/view/gepecid 
olhar para as referências mais citadas está ancorada em dois pressupostos: (i) possibilita entender o "com base em que" os trabalhos qualificam Tema Gerador; (ii) auxiliam na caracterização do "como" está ocorrendo a disseminação do conhecimento Freireano.

Além disso, apresentaram-se duas categorias - derivadas do processo de ATD —, sendo: (1) A valorização do conhecimento por meio da problematização e diálogo: os momentos pedagógicos; (2) Conhecer para transformar com base na contextualização e interdisciplinaridade.

A constituição e validade destas categorias estão ancoradas em respostas à questão “como o Tema Gerador é visto nos trabalhos?", e evidenciam elementos considerados nos processos de obtenção e construção dos Temas Geradores. Reitera-se que tais categorias, podem ser entendidas como articuladas em prol de entender elementos sobre os quais os processos formativos se estruturam, isto é, tem haver com a construção dos Temas Geradores.

A categoria "A valorização do conhecimento por meio da problematização e diálogo: os momentos pedagógicos” está balizada na noção que os autores dos trabalhos possuem, em relação ao conhecimento do educando. Nas práticas, evoca-se a participação dos sujeitos, por meio de ações dialógico-problematizadoras, em vista da promoção da aprendizagem. Faz-se isso, com base nos momentos pedagógicos. Soma-se a tais discussões, os elementos apresentados na categoria "Conhecer para transformar com base na contextualização e interdisciplinaridade", quando se pontuaram elementos que estruturam os trabalhos com os Temas Geradores - os quais possuem uma natureza interdisciplinar e devem trazer à tona os contextos dos mundos vividos em forma de problemas. Assim, os conhecimentos científicos passam a ter um papel de auxiliar no entendimento e transformação local.

Para os sujeitos que estão familiarizados à obra Freireana, a apresentação dos resultados deste estudo pode parecer redundante. Porém, tal apresentação se torna importante tendo em vista a polissemia acerca o entendimento do Tema Gerador. Não se pode esquecer que há sujeitos que - mesmo bem-intencionados - podem não compreender a dimensão do Tema Gerador (e, aqui está-se a falar sobre a compreensão teórica, não dos limites metodológicos impostos pela prática), minimizando o legado epistêmico/curricular Freireano. No limite, os resultados apresentados neste estudo possibilitam compreender elementos, contextos e sujeitos importantes para o desenvolvimento desta perspectiva curricular. Obviamente, tais discussões não se encerram neste estudo.

A compreensão de fatores que potencializam e/ou sustentam a disseminação da perspectiva curricular Freireana, apresentadas neste trabalho, tornam-se necessárias não somente para aqueles sujeitos que já trabalham neste viés. Para estes, o presente trabalho possibilita tomar distância do já visto e vislumbrar novas ações ou, em outras palavras, possibilitam pensar os limites dos conhecimentos e práticas Freireanos. Já para aqueles(as) que estão se inserindo no campo curricular, especialmente de Freire, este trabalho constitui-se como um guia inicial, não único, a fim de mostrar que caminhos 
seguir, o que ler, quem procurar. Este trabalho nasceu da necessidade de resgatar e sistematizar os pensamentos e ações curriculares Freireanas, no campo de Ensino de Ciências, algo inédito. Entretanto, ele não deve se esgotar aqui: é necessário dialogar com sujeitos, pesquisadores/professores, no intuito de caracterizar ainda mais os modos de produção e disseminação do conhecimento curricular Freireano.

A partir deste estudo, almeja-se uma maior união e trabalho coletivo de grupos, Freireanos e Freireanas: é necessário que sejam criadas produções e ações coletivas, sistemáticas, a fim de salvaguardar o legado Freireano. Como exemplo, argumenta-se a favor de trabalhos conjuntos com outras organizações, tal qual o Instituto Paulo Freire.

Em tempos de retrocessos, ataques e opressão, é preciso ser (r)existência, mostrar a importância de uma educação libertadora, ocupar espaços, construir pontes e conhecimentos. Por isso mesmo, Paulo Freire é necessário para que se possa, em coletivos, problematizar e transformar as realidades, de modo dialógico, não esquecendo que a práxis deve ser a via principal. Além disso, Paulo Freire é necessário para quem realmente se coloca à disposição e deseja uma sociedade baseada nos valores humanos básicos, de empatia, de amor, de criticidade, de autenticidade.

\section{Referências}

Amestoy, M., \& Tolentino-Neto, L. C. (2020). Políticas de avaliação e os organismos internacionais: uma relação necessária?. Revista Cocar, 14(28), 824-837. https:// periodicos.uepa.br/index.php/cocar/article/view/3152

Auler, D., Dalmolin, A., \& Fenalti, V. (2009). Abordagem Temática: natureza dos temas em Freire e no enfoque CTS. Alexandria, 2(1), 67-84. https://periodicos.ufsc.br/index. php/alexandria/article/view/37915

Costa, C. G., \& Furtado, E. D. P. (13-15 de maio, 2015). Situações limites na pedagogia do oprimido e da esperança: possibilidades para a formação do educador da EJA. V Seminário Nacional Formação de Educadores de Jovens e Adultos, Campinas, São Paulo, Brasil.

Centa, F. G., \& Muenchen, C. (2016). O despertar para uma cultura de participação no trabalho com um tema gerador. Alexandria, 9(1), 263-291. https://doi.org/10.5007/19825153.2016v9n1p263

Coutinho, R., Dávila, E., Santos, W., Rocha, J., Souza, D., Folmer, V., \& Puntel, R. (2012). Brazilian scientific production in science education. Scientometrics, 92(3), 697-710. http://dx.doi.org/10.1007/s11192-012-0645-5

Delizoicov, D. (1982). Concepção problematizadora do ensino de ciências na educação formal (Dissertação de Mestrado, Universidade de São Paulo, São Paulo, São Paulo).

Delizoicov, D. (1980). Uma experiência em ensino de ciência na Guiné Bissau Depoimento. Revista de Ensino de Física, 2(4). 
Delizoicov, D., Angotti, J. A., \& Pernambuco, M. M. (2011). Ensino de Ciências: fundamentos e métodos. Paz e Terra.

Delizoicov, D., Delizoicov, N. C., \& Silva, A. F. G. (2020). Paulo Freire e o ser humano em processo de formação permanente. Retratos da Escola, 14(29), 353-369. https://doi. org/10.22420/rde.v14i29.1155

Delizoicov, D., \& Zanetic, J. (2002). A proposta de interdisciplinaridade e seu impacto no ensino municipal de $1^{\circ}$ grau. In N. N. Pontuschka. Ousadia no diálogo: interdisciplinaridade na escola pública. Loyola.

Fonseca, K. N., Novais, E. S. P., Neres, C. A., Barbosa, L. S., Mili, J. C. L., \& Gehlen, S. T. (24-27 de novembro, 2015). Tema Gerador em Pesquisas em Educação em Ciências. X Encontro Nacional de Pesquisas em Educação em Ciências, Águas de Lindóia, São Paulo, Brasil.

Freire, P. (1987). Pedagogia do Oprimido. Paz e Terra.

Frigotto, G. (2008). A interdisciplinaridade como necessidade e como problema nas ciências sociais. Ideação, 10(1), 41-62.

Gadotti, M. (2000). Perspectivas atuais da educação. São Paulo em Perspectiva, 14(2).

Gehlen, S. T. (2009). A função do problema no processo ensino-aprendizagem de ciências: contribuições de Freire e Vygotsky (Tese de Doutorado, Universidade Federal de Santa Catarina, Florianópolis, Santa Catarina). Repositório Institucional da UFSC. http:// repositorio.ufsc.br/xmlui/handle/123456789/92543

Ingrassia, T. (2018). A atualidade do pensamento pedagógico de Paulo Freire. CirKula.

Magoga, T. (2017). Abordagem Temática na Educação em Ciências: um olhar a partir da epistemologia Fleckiana (Dissertação de Mestrado, Universidade Federal de Santa Maria, Santa Maria, Rio Grande do Sul). Repositório Digital da UFSM. http://repositorio.ufsm. br/handle/1/12753

Magoga, T. (2021). Estilo de Pensamento Curricular Freireano: sujeitos, contextos e elementos (Tese de Doutorado, Universidade Federal de Santa Maria, Santa Maria, Rio Grande do Sul).

Magoga, T., \& Muenchen, C. (2018). A Abordagem Temática na Educação em Ciências: a caracterização de um estilo de pensamento. Alexandria, 11(2), 131-157. https://doi. org/10.5007/1982-5153.2018v11n2p131

Malheiros, A. P. S., \& Forner, R. (2020). Um olhar Freireano para a Base Nacional Comum Curricular de matemática. Olhar de professor, 23, 1-14. https://doi.org/10.5212/ OlharProfr.v.23.2020.16225.209209229410.0828

Moraes, R., \& Galiazzi, M.C. (2007). Análise textual discursiva. Unijuí. 
Muenchen, C. (2010). A disseminação dos Três Momentos Pedagógicos: um estudo sobre práticas docentes na região de Santa Maria (Tese de Doutorado, Universidade Federal de Santa Catarina, Florianópolis, Santa Catarina). Repositório Institucional da UFSC. http://repositorio.ufsc.br/xmlui/handle/123456789/93822

Muenchen, C., \& Delizoicov, D. (2014). Os Três Momentos Pedagógicos e o Contexto de Produção do Livro "Física". Ciência \& Educação, 20(3), 617-638. https://doi. org/10.1590/1516-73132014000300007

Paniz, C. M., \& Muenchen, C. (2021). O Estudo da Realidade e os Temas Geradores no Ensino de Ciências: reflexões sobre um processo vivenciado no contexto do PIBID. Ensino de Ciências e Tecnologia em Revista, 10(1), 56-72. http://dx.doi.org/10.31512/ encitec.v10i1.3028

Pernambuco, M. M. (2002). Quando a troca se estabelece (a relação dialógica). In N. N. Pontuschka. Ousadia no Diálogo: Interdisciplinaridade na escola pública. Loyola.

Pernambuco, M. M. (1994). Educação e escola como movimento: do ensino de ciências à transformação da escola pública (Tese de Doutorado, Universidade de São Paulo, São Paulo, São Paulo).

Pierson, A. H. C. (1997). O cotidiano e a busca do sentido para o ensino de Física (Tese de Doutorado, Universidade de São Paulo, São Paulo, São Paulo).

Secretaria Municipal de Educação de São Paulo - SME-SP (1992). Ciências: Visões da área, coleção de autores coletivos.

Saul, A. M. (2014). Políticas e práticas educativas inspiradas no pensamento de Paulo Freire: pesquisando diferentes contextos. Currículos sem Fronteiras, 14(3), 129-142.

Schneider T. M., Centa, F. G., \& Magoga, T. (22-23 de maio, 2015). Um olhar para a definição dos temas geradores em práticas educativas de educação em ciências baseadas na abordagem temática. XVII Fórum de Estudos: Leituras de Paulo Freire. Santa Maria, Rio Grande do Sul, Brasil.

Silva, A. F. G. (2004). A construção (Tese de Doutorado, Pontifícia Universidade Católica de São Paulo, São Paulo, São Paulo). Biblioteca Digital: Teses e Dissertações PUC. https:// tede2.pucsp.br/handle/handle/22098

Silva, T. T. (2011). Documentos de Identidade: Uma introdução às teorias do currículo. Autêntica.

Torres, J. R. (2010). Educação Ambiental Crítico-Transformadora e a Abordagem Temática Freireana (Tese de Doutorado, Universidade Federal de Santa Catarina, Florianópolis, Santa Catarina). Repositório Institucional da UFSC. http://repositorio.ufsc.br/xmlui/ handle/123456789/93568 
Voltas, F. Q., Saul, A. M., \& Saul, A. (2021). Formação permanente Freireana na Educação de Jovens e Adultos: reinventando políticas e práticas no município de São Paulo. Práxis Educativa, 16, 1-19. https://doi.org/10.5212/PraxEduc.v.16.16601.002

Watanabe, G. (org.) (2019). Educação Científica Freireana na escola. Livraria da Física.

\section{Apêndice}

\begin{tabular}{|l|l|}
\hline $\begin{array}{l}\text { Código (Evento_Ano_ } \\
\text { notrabalho) }\end{array}$ & Título do trabalho \\
\hline SNPF_2016_5 & $\begin{array}{l}\text { Problemas ambientais como temas geradores a serem levados ao círculo de } \\
\text { cultura em uma escola de periferia. }\end{array}$ \\
\hline FEL_2015_8 & $\begin{array}{l}\text { Abordagem temática: contextualizando a investigação de temas geradores } \\
\text { na escola }\end{array}$ \\
\hline FEL_2017_6 & As concepções sobre tema gerador de bolsistas e supervisores do PIBID \\
\hline ENEQ_2014_23 & $\begin{array}{l}\text { Drogas como tema gerador: contribuição para uma metodologia educativa } \\
\text { crítica }\end{array}$ \\
\hline ENEQ_2016_16 & A contextualização no ensino de química por meio de contos. \\
\hline ENEQ_2016_21 & $\begin{array}{l}\text { A pergunta do aluno como subsídio para elaboração de uma sequência } \\
\text { didática sobre o tema petróleo }\end{array}$ \\
\hline SNEF_2009_2 & $\begin{array}{l}\text { Uma proposta de ensino e aprendizagem de física por meio da } \\
\text { problematização do cotidiano }\end{array}$ \\
\hline SNEF_2013_4 & $\begin{array}{l}\text { “Armas: segurança ou insegurança?”: uma experiência com o ensino de } \\
\text { física }\end{array}$ \\
\hline SNEF_2015_8 & $\begin{array}{l}\text { A organização de atividades didático-pedagógicas de ciências baseada no } \\
\text { tema gerador: “o perigo do rioÁgua preta em Pau Brasil/BA" }\end{array}$ \\
\hline SNEF_2017_5 & $\begin{array}{l}\text { Contribuições da física para a conservação da carne vendida na feira do } \\
\text { bairro de Fátima em Itabuna/BA }\end{array}$ \\
\hline ENPEC_2013_12 & $\begin{array}{l}\text { A contextualização na abordagem temática Freireanae no ensino de } \\
\text { ciências por investigação }\end{array}$ \\
\hline ENPEC_2017_4 & Matriz de referência CTS: análise da natureza de um tema gerador \\
\hline ENPEC_2017_8 & $\begin{array}{l}\text { Trabalhando conceitos químicos na EJA por meio da concentração de } \\
\text { bebidas alcoólicas }\end{array}$ \\
\hline ENPEC_2017_27 & Abordagem temática freireana em uma escola estadual no maranhão \\
\hline ENPEC_2017_42 & $\begin{array}{l}\text { Educação do campo e ensino de ciências: contribuições da perspectiva } \\
\text { freireana para o trabalho docente }\end{array}$ \\
\hline
\end{tabular}


Thiago Flores Magoga

Universidade Federal de Santa Maria Santa Maria, Rio Grande do Sul, Brasil thiago.ufsm@gmail.com

\section{${ }^{0}$ Cristiane Muenchen}

Universidade Federal de Santa Maria Santa Maria, Rio Grande do Sul, Brasil crismuenchen@yahoo.com.br 